\title{
Dutifully Wishing: Kant's Re-evaluation of a Strange Species of Desire
}

\section{Alexander T. Englert}

\begin{abstract}
For Kant, 'wish' is a technical term denoting a strange species of desire. It is an instance in which someone wills something that she simultaneously knows she cannot bring about. As a result, it is, in one sense, antithetical to morality, which deals with 'ought implies can'. I will argue that Kant re-evaluated wishing as (to some extent) causally efficacious and, further, of moral relevance. This re-evaluation has not been discussed in the literature, yet has been lurking in plain sight in a subtle shift in two versions of a footnote from the Critique of the Power of

\section{Judgement.}

Keywords: wishing, highest good, Critique of the Power of Judgement, will, morality, action, religion
\end{abstract}

\section{Introduction}

Kant uses 'wish' as a technical term to denote a strange species of desire. ${ }^{1}$ It is an instance in which someone wills an object that she simultaneously knows she cannot bring about. Or in more Kantian garb: it is an instance of the faculty of desire's (or will's) failing insofar as a desire (representation) cannot be the cause of the realization of its corresponding object in reality. ${ }^{2}$ As a result, Kant originally maintained it to be antithetical to morality, which deals with 'ought implies can'. However, Kant's notion of wish is not static. On the contrary, I argue in this article that Kant re-evaluated the capacity to wish as (to some extent) causally efficacious and, 
further, of moral relevance. This re-evaluation has not been discussed in the literature, ${ }^{3}$ yet has been lurking in plain sight in a subtle but decisive shift evident in two versions of a footnote from the Critique of the Power of Judgement (hereafter: $K U)$.

Though subtle, the shift is stark. In the first introduction of the $K U$, in approximately 1789 , Kant excoriates the human capacity to wish in a lengthy footnote. He asserts that not only is wishing a moment of human incapacity, it is further something that morality should warn against, a product of reading too many novels, and nothing more than an anthropological baby step in understanding the limits of one's powers. This excoriation never made it into the first edition of the $K U{ }^{4}$ However, by $1793 \mathrm{Kant}$ had reinserted the footnote into the second edition corrections with a completely different, positive take. After finding wish to be an idle folly for so long, Kant surprisingly presents wishing as an efficacious capacity and causal in so far as it leads us to strive towards objects about whose ultimate realization we must remain agnostic. Moreover, he removes his moral warning against it and even attributes teleological importance to it.

This article has two objectives: one historical and the other theoretical. The historical objective is to present the elements of wishing before and after Kant's change of heart (sections 2 and 3 ), and then to offer an immanent reconstruction as to why this change of heart most likely occurred (section 4). My detailing of the elements of wishing stands regardless of whether section 4 succeeds or fails. The theoretical objective is to detail the positive, causal sense of moral wishing in its most explicit form (section 5); then (section 6) I unpack moral wishing in contrast with idle wishing with an eye to its relevance for action. 


\section{Elements of Wishing: Take One (1789)}

In the original footnote of the first introduction, Kant reflects on a criticism made of his definition of the faculty of desire by August Wilhelm Rehberg in $1788 .^{5}$ Rehberg, in his review of Kant's Critique of Practical Reason (hereafter: $K p V$ ), charges that Kant's definition of the faculty of desire proves inconsistent. The faculty of desire, for Kant, is defined as 'the faculty for being, through its representations, the cause of the reality of the objects of these representations' (KU, 20: 230n). Rehberg points out, however, that wishing is a form of desire yet it is a desire that cannot be the cause of the reality of its represented object. Kant's transcendental definition, thus, seems in danger of being undermined by an instance of everyday desiring.

Kant's response to this challenge reveals the basic elements of his initial thoughts on wishing. ${ }^{6}$ First, Kant originally held that this exception to the transcendental definition 'proves nothing more than that there are also determinations of the faculty of desire in which it is in contradiction with itself' $(K U, 20: 230$ n.). Although of interest to empirical psychologists, it need not concern philosophers. To illustrate this point, he draws a parallel to the fact that one can be interested in how 'prejudices' influence logic, even though the deleterious influence on sound reasoning need not be taken up by logicians. The transcendental definition, or the faculty 'considered objectively' (ibid.), therefore, remains unaffected by this species of desire. Two conclusions can be drawn from this initial positioning. First (i), Kant considered wish at this time of psychological and not of philosophical interest. And second (ii), Kant's position takes the faculty of desire's transcendental, or objective, definition as pertaining to its operations 'before it is deflected from its determination by something else' (ibid.). In short, a transcendental 
definition of our faculty of desire need not concern itself with contradictions or failures in its operations.

This delimiting of the transcendental sphere and the role of the faculty of desire within it brings us the final two elements of the initial footnote. After Kant's initial discussion of wish and its lack of philosophical importance, he asserts that:

[i]t is important for morality to warn emphatically against such empty and fantastic desires, which are frequently nourished by novels, and sometimes also by mystical representations, similar to novels, of superhuman perfections and fantastical bliss. (KU, 20: 231n.)

Here we hold two points separate. There is (iii) Kant's ('emphatic') warning against wishing for morality, and (iv) Kant's anthropological considerations as to its genesis. Regarding (iii), Kant offers only fleeting remarks here. He claims that such wishing is detrimental due to its 'overexciting and enfeebling the heart', which in turn can exhaust it; a further remark is that wishing represents a 'fruitless expenditure of our powers' (ibid.). A fuller justification of this criticism of wishing can be found in his Lectures on Anthropology. ${ }^{7}$ The main danger seems to lie in wishing leading us astray from our moral vocation of realizing the moral law in the here and now. In contrast to the 'ought' of the moral law, the siren call of our wishes presents us with a representation that 'cannot move our activity' ( $V$-Anth/Pillau, 25: 795) and yet gratuitously wastes our volitional energies. As an incontinent instance of willing, it serves as a bad example for morality, which is in the business of 'ought implies can'; and as a wasted expenditure of volitional energy, it distracts and depletes us in pursuits offering no physical or moral reward. 
Briefly, regarding (iv), Kant ends on a lighter note, in that he trusts the wise workings of nature due to wishing putting us in a position to train our volitional muscles: 'For we commonly learn to know our powers only by trying them out' $(K U, 20: 231 \mathrm{n}$.). Kant sees in wishing proof of a unification of the determination of our powers and our representations of objects 'even prior to knowledge of our capacity'; wishing, as a consequence, remains deeply ingrained in our nature, though 'wisdom is obliged to set limits for this instinct' (ibid.).

In summary, Kant attacks wish on four fronts in order to defend his transcendental definition of the faculty of desire from Rehberg's accusations of inconsistency. These four fronts are:

(i) Wishing has no philosophical importance.

(ii) Wishing, as an incapacity, cannot in any way serve in a transcendental definition of the faculty of desire.

(iii) Wishing is harmful to morality.

(iv) Wishing might be beneficial when taken up from an anthropological point of view, but that is all that can be said on the matter.

Of most salience is his charge in (ii) because it lays the grounds for why wishing is of no philosophical importance and harmful to morality (i.e. from it both (i) and (iii) follow). Charges (ii) and (iii) are furthermore of interest, because they are removed from the second edition version of the footnote and completely replaced. Charge (iv) is important as well for how it changes in light of the $K U$ 's Doctrine of Method.

\section{Elements of Wishing: Take Two (1793)}

Naturally, when looking toward the published version in 1790 , one sees no evidence of any of these considerations. Kant struck the footnote entirely from the first edition introduction. 
Nevertheless, by October 2, 1792, Kant had reinserted the footnote in the manuscript that he sent Lagarde for the second edition. We know, further, that Kant highly valued this addition. Indeed, Kant refers to it in his letter to Lagarde as the 'only important [correction]' in the new edition $(\mathrm{Br}$ [Letter 533], 11: 373), a point he highlights in order to reject Lagarde's request to market the book as, so to speak, new and improved. Albeit not evident at first blush, the changes to the footnote are indeed dramatic.

Kant begins nearly verbatim and refers again to the objection posed by Rehberg. Importantly, however, he changes the manner in which he presents wish as standing opposed to the definition of the faculty of desire. Whereas in the first introduction, Kant describes wish as challenging the definition, 'since mere wishes would also be desires, which, it is nevertheless admitted, cannot bring forth their objects' $(K U, 20: 230 \mathrm{n}$.), in the second edition he adds a crucial phrase: wishing challenges the definition, 'because mere wishes are also desires, but yet everyone would concede that he could not produce their object by their means alone' (KU, 5: 177, my emphasis). The addition of the four last words changes the very definition of wish. Previously (in charge (ii) of section 1 above), wish remained exclusively an incapacity, which, in turn, defused its threatening the transcendental definition of the faculty of desire. Now, wishing represents an object of desire that one can possibly attain should something else aid one in her attempts.

Moreover, Kant does not make any claims against wish being of philosophical importance, nor does he chastise wish as a juvenile pursuit spurred on by the reading of too many novels. $\mathrm{He}$ simply goes on to state that the nature of wish 'proves nothing more than that there are also desires in a human being as a result of which he stands in contradiction with himself, in that he works toward the production of the object by means of his representation alone, from which however he can expect no success' $(K U, 5: 177 \mathrm{n}$.). Though Kant calls wish again a moment of 
the agent in contradiction with herself, there is a distinct difference between the two editions. One difference lies in the fact that Kant treats the wished for object in the second edition version as efficacious in bringing one to 'work towards its production'. He now takes wish as definitively efficacious. In the unpublished first introduction, he came closest to this not in its definition but rather in his anthropological hypothesis. Also, Kant now leaves open whether the desired object can or cannot be brought about. He points to our 'expectation' that it cannot come about; however, we no longer are 'convinced that [we] cannot accomplish it or even that it is absolutely impossible' (KU, 20: $231 \mathrm{n}.)^{8}$

Finally, to put charge (ii) definitively to rest, Kant claims explicitly that wish is a type of desire paradigmatic to the transcendental definition of the faculty of desire. Due to its importance, I quote the passage in its entirety:
Although in the case of such fantastic desires we are aware of the inadequacy of our representations (or their unsuitability) to be causes of their objects, nevertheless their relation as causes, hence the representation of their causality, is contained in every wish, and it is especially visible if this is an affect, namely longing. (KU, 5: 178n.)

We see that wish, rather than falling outside the transcendental definition of the faculty of desire, represents one species of its genus, albeit an odd one at that. Moreover, we see Kant replace his charges of (i) and (ii) with the following endorsements:

(I) Wishing can be of philosophical importance.

(II) Wishing, as a representation of one's causality, is consistent with the transcendental definition of the faculty of desire. 
It should be noted that (I) follows from (II). And (II) can be grounded on the multiple changes just laid bare. Kant treats wish now as the ability to have a causal representation that moves us despite our knowledge that we cannot realize it on our own. From this, we can now frame the most pertinent question of all: do these revisions of Kant's position, along with his remitting the warning of morality against it, suggest that wish is important for moral practical reason? To answer this question one must look beyond the footnote. Importantly, within the footnote, the closest Kant comes is in claiming that even prayers for the 'avoidance of great and so far as one can see unavoidable evil' and for the attainment of 'naturally impossible ends prove the causal relation of representations to their objects' $(K U, 5: 178 \mathrm{n}$.). Though not quite explicit, this reference to prayer provides textual evidence pointing toward wish as not only morally pertinent, but rather as a duty itself. I return to this in Section 5.

Even before presenting my evidence, however, one can make the potential of its moral import intuitively clear. If one considers the importance of the highest good as a final end to be willed, but which we cannot hope to bring about by our powers alone, one understands the appeal of including wish as an instance of the pure faculty of desire. The reason? This would offer transcendental grounding for the motivation behind our striving to realize the highest good, which otherwise might lack any motivation if searched for in our sensible nature. I put forward as a working hypothesis (which I later support):

(III) Wishing plays a role important to morality.

As regards (iv), there is one serious change in the second edition footnote, which makes it of great interest and draws us to look for grounds of its addition in the Doctrine of Method of the $K U$. Kant now adds that $w h y$ we wish is not just a question for anthropological investigations; 
rather it 'is an anthropological-teleological question' (KU, 5: 178n., my emphasis). The fact that Kant now thinks of the origins of wishing as an 'anthropological-teleological' question makes it clear that wishing has found its rightful place within the $K U$. Kant ends the footnote by calling 'empty wishes' and the 'illusion' thereby created 'the consequence of a beneficent arrangement of our nature' $(K U, 5: 178 \mathrm{n}$.$) . We are drawn then to replace (iv) with:$

(IV) Wishing plays a teleological function for humanity as a whole.

As such, wishing becomes a characteristic mark of humanity - it is not simply something that represents an agent in contradiction with herself, rather it plays a teleological role for the human species as a whole. Thus we see wishing raised up from an idle, contra-moral and fruitless expenditure of energy to a 'beneficent arrangement of our nature', and one that is causally efficacious despite its object (whatever that may be) stretching beyond one's individual powers.

\section{The Object For Which We Wish}

Wish has re-entered the $K U$ three years after its original publication. However, now it has transformed from a topic of interest only to psychologists into a species of human causality relevant to philosophical discussions of morality and teleology. What immanent reasons brought Kant to this about-face regarding wishing? I think two steps in relation to the highest good are to thank: first, his connection of the highest good with teleology as the 'final end of creation'; and, second, his introducing a species-level duty for us to work towards it - in Religion Within the Boundaries of Mere Reason (hereafter: $R G V$ ). I argue that in order to allow us qua species to fulfil this unique kind of duty, Kant needed moral wishing as a strange species of desire. Due to limitations of space, I can only sketch what I believe brought Kant to re-evaluate wishing in a moral sense; consequently, I pass over many controversial points worth independent discussion. 
Step 1: Starting with the $K U$, the first major clue is to be found in the Doctrine of Method. There, Kant calls the human being 'the ultimate end [letzter Zweck] of creation here on earth' $(K U, 5: 426-7){ }^{9}$ In contrast to all other creatures, it is only the human being who can become a master of 'ends'. We cannot help but view ourselves as ends, we are intentional beings who set ourselves the task of achieving certain ends, and via our scientific research we can 'make a system of ends out of an aggregate of purposively formed things' ( $K U, 5: 426-7)$. When we are 'necessarily' led 'to the idea of a whole of nature as a system in accordance with the rule of ends' (KU, 5: 379), we must assume an unconditioned final end to anchor this teleological whole. ${ }^{10}$ If we search for the absolute end of creation in ourselves, none of our finite ends or the contingent state of personal happiness can qualify to be nature's 'final end' (Endzweck). Only one end suffices, 'namely, the aptitude for setting [oneself] ends at all... using nature as a means... of [one's] free ends in general, which nature can accomplish with a view to the final end that lies outside of it' (KU, 5: 431). The final end is 'final' precisely because it is outside any particular, contingent moment of creation and aimed at formal end-setting as such, i.e. towards our freedom expressing reason's shared moral vocation. As a result, one takes the final end of creation to be aimed at a communal system that allows for the greatest degree and freedom of end-setting by the greatest number of persons possible, namely, 'by lawful power in a whole, which is called civil society' (KU, 5: 432).

While a pure practical ideal in the $K p V$ that might be possible if one postulates certain supersensible ideas, ${ }^{11}$ the highest good as the end of creation changes conceptual shape. For in the $K p V$, the a priori principle of purposiveness was not yet part of the transcendental system. With the highest good becoming the end of creation, however, I think Kant came to realize that he needed to avoid referring to it as, in principle, impossible in this world because of his notion 
of ends in general. For something whose end is simultaneously impossible for it in reality would result in a teleological contradiction. ${ }^{12}$ It follows that - as the teleological endpoint of creation we must think of the highest good as, in principle, either 'possible' or, agnostically, 'neither possible nor impossible'. That is, in this world it cannot already be ruled impossible if we are to work towards it intentionally - i.e. even if there is a God, we should act like it is up to us and so remain agnostic as to our ability in helping to realize it. And it is precisely this formulation that we get in the $K U$ 's Doctrine of Method, where Kant concludes we have rational grounds for maintaining faith, ${ }^{13}$ 'on account of the obligation to [the highest good], although we can have no insight into its possibility or into its impossibility' (KU, 5: 472, my emphasis). The fact that the possibility or impossibility is left unknown sheds - what I have already referred to as - an agnostic light on the concept of the highest good. Moreover, the footnote attached to this passage and one of the only other major changes Kant made to the second edition of the $K U$ (apart from the revised footnote on wishing) goes as follows:

It is a matter of trusting the promise of the moral law [...] For a final end cannot be commanded by any law of reason without reason simultaneously promising its attainability, even if uncertainly, and hereby also justifying the affirmation of the only conditions under which our reason can conceive this. (KU, 5: 471-2n., my emphasis)

I would like to highlight these references to suspending judgement regarding the highest good's possibility or impossibility since they reflect some changes we found in the altered footnote on wishing. Here is solid textual evidence for seeing the major additions in the second edition, the one in the introduction and the one here, as connected in purpose. The question they attempt to 
answer is: if I cannot help but see the highest good as the teleological end of creation, how can I continue to refer to it as, in principle, impossible?

The highest good as a teleological concept requires more openness for us in approaching it vis-àvis its possibility or impossibility. Moreover, if we remain agnostic as to its impossibility, then it seems perfectly rational to assume that it might come about in the course of human events. Perhaps because of this new teleological component, Kant also began emphasizing our need to strive after the highest good: '[The moral law] determines for us ... a final end, to strive after which it makes obligatory for us' $(K U, 5: 450)$. This point he stresses even further by reference to our individual 'powers': 'We are determined a priori by reason to promote with all our powers what is best in the world' ( $K U, 5: 453$, my emphasis). He even goes so far as to say that in order to serve this demand, to strive after it, we can assume (practically) its 'realizability': 'Now in virtue of the moral law ... we have a basis for assuming, from a practical point of view, that is, in order to apply our powers to realize [the final end], its possibility, its realizability' ( $K U, 5: 455$, my emphases). The thought of its realizability is further strengthened from the results of the analytic portions of the $K U$, where it was shown that in reflective judgements of beauty and nature, we must further assume possible (because of the principle of purposiveness being an objective fact of experience) the bridging of moral, practical laws and natural, theoretical laws. ${ }^{14}$ However, in the $K U$ we still must assume the existence of God, albeit now as a moral author of the universe. ${ }^{15}$

Ultimately, the $K U$ sets the stage for moral wishing becoming germane to moral considerations. However, the final pieces of the puzzle are not found in the $K U$. Instead, one must look to the intervening years between the publication of the first and second editions for a full understanding of his re-evaluation of wishing, namely, to the time in which Kant was working on $R G V .^{16}$ The 
reason, I conjecture, has to do with a tension in the $K U$ 's account of the highest good. For on the one hand, Kant claims that the highest good as the final end of creation must be realized in the form of a civil society: 'for only in this can the greatest development of the natural predispositions occur' $\left(K U, 5: 432\right.$, my emphasis). ${ }^{17}$ On the other hand, he also claims that 'if reason is to provide a final end a priori at all, this can be nothing other than the human being (each rational being in the world) under moral laws' $(K U, 5: 448)$. The problem is that civil society (as the 'only' way to realize the final end of creation) arises via external coercion. The final end of creation, however, is determined by 'nothing other' than our inner moral vocation.

Step 2: Since the highest good is derived from our moral vocation, we need a duty that points towards such a teleological end without depending solely on external coercion. Supporting my reading, Kant warns precisely against such an arrangement in $R G V$ : 'But woe to the legislator who would want to bring about through coercion a polity directed to ethical ends!' ( $R G V, 6: 96)$. We need the highest good qua end of creation married to a moral vehicle for arriving at its destination. Following this passage, Kant introduces precisely such a duty for striving after the highest good, namely, a duty of a special and unique kind:

Now, here we have a duty of a kind all its own [von ihrer eigenen Art], not for human beings but of the human race toward itself. For every species of rational being is objectively - in the idea of reason - destined to a common end, namely the promotion of the highest good as a good common to us all. ( $R G V, 6: 97$, translation altered)

Bringing about the highest good is now a duty of our species to itself. It is more than just a pure ideal object of pure practical reason, more than just the final end of creation. Now, it has won 
concrete form as a social good of our species. Such a state is radically different from the perfect civil constitution of the $K U$. For such a state depends on laws that coerce its members from without; by contrast, an 'ethico-civil state is one in which they are united under laws without being coerced, i.e. under laws of virtue alone' ( $R G V, 6: 95)$. Kant is coming to terms with how such a highest good qua social good can come about - and since derived from our moral vocation, the motivation must be virtuous.

Here we see a new element connect with the highest good, namely, the notion of a species-level duty. Key to understanding its relevance to wishing, I propose, is its strange character as a duty of a kind all its own. For it is here that we see Kant return to the notion of a need to strive as a species for this final end of creation: '[T]his highest moral good will not be brought about solely through the striving of one individual person ... but requires rather a union of such persons into a whole toward that very end' $(R G V, 6: 97)$. Yet our duty qua species-members remains unique because 'it is the idea of working toward a whole of which we cannot know whether as a whole it is also in our power' $(R G V, 6: 98)$. And I think it was in thinking about this unique notion of a species-level duty that Kant came to re-evaluate wishing in a certain moral sense. Indeed, his first strong formulation of wishing in the moral sense occurs shortly after this account of our duty as a species: 'The wish of all well-disposed human beings is, therefore, "that the kingdom of God come, that His will be done on earth"' $(R G V, 6: 101)$. As a member of our species, we are duty bound. However, in contrast to a moral action that I can directly perform, the highest good (as the ethico-civil state) will never become an object of intuition. Still, as a member of a species, the highest good might be possible if we all 'are united for a common effect' ( $R G V, 6$ : 98). 
Now we see one possible explanation for why Kant (according to (IV) from section 3 above) refers to wish as something of 'anthropological-teleological' interest. As human beings, we must take ourselves to be the 'titular lord of nature' $(K U, 5: 431)$. Because the highest good is now the final end of creation, one can rightfully say that our own purposiveness qua moral vocation must aim towards bringing about our end as a species, namely, the social good. But how can we hope to work towards this as a species? It seems as if we need some form of desire that will accommodate a duty where we are not directly bound to bring about our object and that in some sense allows us to strive towards it all the same.

At this point, if we were to look for an answer in Kant's thinking around 1789, i.e. around the time of the never-published first introduction footnote, then the answer would be: no such desire exists for us as individuals. Our faculty of desire (in transcendental terms) is the capacity that via representations can cause the realization of the corresponding object of said representations. Consequently, working towards our species-level duty would represent but a moment of our incapacity, a moment of idle wishing. Rehberg's criticism would be even more crushing than originally expected. We would have to abandon all hope of being up to the task of realizing the highest good in solidarity with the rest of humanity.

Again: the new problem seems to be that our moral potency as a species, if left unchanged, remains in need of supplementation. As part of the solution to this problem, Kant introduces moral wishing in the 'doctrine of blessedness' as a necessary addition 'supplementing our [individual] incapacity with respect to the final moral end' ( $R G V, 6: 183$, translation altered). Kant states further that 'divine blessedness cannot of itself constitute the final end of moral striving but can only serve as a means of strengthening what in itself makes for a better human being' (ibid., my emphasis). Divine blessedness does this 'by holding out to this striving and 
[portending and securing] for it ... the expectation of the final end for which it is itself powerless' (ibid.). ${ }^{18}$ In these passages, Kant gives the sufficient condition for acting on our species-level duty; the necessary condition, which comes first, is duty as such. As will be detailed in the next section, the key is that this notion of moral striving, of moral 'strengthening' to become a 'better human being', is not rooted in external actions but rather in internal actions on one's character, one's moral disposition.

This concludes my attempt to reconstruct the immanent evolution of the highest good that brought Kant from his original position in 1789 - when wishing seemed moot for his transcendental philosophy - to his re-evaluated position of 1793. Even if one disagrees with the route taken to arrive here, the destination that I now explore remains worth thorough study, for it fills out the incomplete picture of Kant's positive take on wishing (from section 3) and secures its moral relevance.

\section{Moral Wishing}

If I am correct, then Kant changed his mind about the nature of wish due to the highest good as a social good becoming the end of creation and a duty of our species to itself. If it were not for these developments, one could conceivably continue to treat wishing as a superfluous phenomenon of our will. But if we have a duty to act together in bringing about the highest good, then there must be a way to will this object together, even if we cannot directly bring it about. But what sort of desire allows us to will something that works indirectly towards its goal? I think that the answer is: one that strengthens our moral disposition - i.e. helps make us better human beings. Since our duty as a species requires that each of us become citizens of an ethical commonwealth, we need a direct way of working on our dispositions to indirectly push humanity nearer to the highest good. While Kant already mentions moral wishing after introducing our 
species-level duty, he only explicitly develops it in discussing our 'observances of duty' at the culmination of Part Four of $R G V(6: 193)$ and in connection with the doctrine of blessedness discussed in the previous section. These observances of duty deal, as already mentioned, with precisely this task of making ourselves better human beings.

We need only concern ourselves with the first of these observances of duty since it is where Kant details moral wishing, which he identifies with the 'spirit of prayer' ( $R G V, 6: 194-5)$. Moral wishing (qua spirit of prayer) is an observance of duty to establish '[the moral] good firmly within us', and 'to awaken [repeatedly] in our heart the disposition for it (private prayer)' ( $R G V$, 6: 193) ${ }^{19}$ Specifically, it is one's persisting wish to be worthy of membership in the Kingdom of God. Most important, however, is that this wish is a duty. Kant posits that the 'heartfelt wish' to be of perfect moral character is something that "can and ought to be in us "without ceasing"" ( $R G V, 6: 194-5$, my emphasis). I would like to underline this point: we can and ought to maintain a heartfelt wish without ceasing! We should not only act morally, but work on ourselves to be moral actors. In so doing, we work on our 'disposition that accompanies all of our actions' (ibid.). What this heartfelt wish constitutes in detail requires full citation from the key footnote:

One finds in [the spirit of prayer] but the resolution [Vorsatz] to good life-conduct which, combined with the consciousness of our frailty, carries with it the standing [beständigen] wish to be a worthy member in the Kingdom of God; hence contains no actual request for something that God in his wisdom might perhaps refuse but a wish instead which, if earnest (efficacious [tätig]), will itself bring about its objective (to become a human being well-pleasing to God). ( $R G V, 6$ : 195n.) 
In order to get all the relevant material on the table, it must also be pointed out that Kant sees the spirit of prayer as simultaneously an observance of duty in a public sense. This public sense holds so long as it does not serve as a specious commitment to the highest good, but rather as an earnest (and, thus, efficacious) 'moral wish' with a 'special purpose', namely, one to 'all the more excite the moral incentives of each individual through an external solemnity which portrays the union of all human beings in the shared desire for the Kingdom of God' $(R G V, 6: 197 \mathrm{n}$.). Thus, to keep oneself awake and primed for moral action, one ought (both privately and publically) to maintain a standing moral wish to be and become of such a moral disposition that one is worthy of such a kingdom.

Out of all this, we see Kant's notion of moral wishing crystallize. It is an observance of duty both personally and publically. On the personal level, the individual's wish to improve her disposition is one related to no outside object. Instead, it is related internally to one's disposition that is responsible for the realization of actions into external states of affairs. As a result, it is something that can be efficacious in so far as the object to be affected is nothing other than one's own moral disposition - the soil out of which one's moral actions grow. The active wish that we exert on ourselves 'without ceasing' serves as a mental marker tacked onto our character. The wish to be worthy of a Kingdom of God is a representation with causal force in so far as it primes our readiness to act morally when confronted with a choice. This primed position, in turn, prepares us to be moral, i.e. increases our attentiveness to strive, grounded in our desire to be of good character. ${ }^{20}$ By maintaining this standing, efficacious wish without ceasing, we make real and present to mind that duty which is shared by our species under the moral law. For the sake of my thesis, the fact that prayer is also drawn upon as an example in the revised footnote of 
the second edition of the $K U$ offers explicit textual indication that Kant was working out his ideas on wishing in tandem with the changes to the second edition publication of the $K U$.

The public level of wishing, however, plays an important subsequent role. For imagining a lone, moral being inhabiting a world of devils, it is difficult to imagine someone with a constitution similar to ours (namely, prone to wear, tear and exhaustion) as fighting for a moral, highest end if no one else aids her in the cause. Thus we have an obligation to keep the spirit of prayer alive communally as well as personally. If we come to believe in a 'union' of moral dispositions towards a shared end, our motivation might be fuelled and real action result. Thus a moral wish is something that is set into motion by individuals but kept going with momentum by human beings as a species. Moral wishing becomes that which causally links up our desires to bring about an end that we cannot expect to bring about individually. And it becomes our duty to persist in our wishing since it holds awake our moral striving. ${ }^{21}$

By analysing the spirit of prayer, Kant has found a species of desire that he originally thought to be impossible: namely, a desire that is causal via a representation but which cannot bring about a corresponding object of the motivating representation through concomitant action.

\section{Idle Wishing vs. Moral Wishing - Philosophical Afterthoughts}

We have then two completely distinct and sovereign forms of wishing. One, idle wishing, conforms to Kant's earliest estimation of those fantasies encouraged by too much reading of novels. The other, moral wishing, is a new breed of desire that articulates a causal capacity of the human being. It is a capacity to cultivate one's moral disposition via a standing wish to see a moral world brought to pass. ${ }^{22}$ 
As a sort of conclusion, I will set out in brief some of the key ways in which idle and moral wishing differ and explore moral wishing's causal component in action. One respect in which idle and moral wishing differ substantially is not in the logical structure of wishing itself, but rather in the nature of its object. In the idle wish, the desired object might be impossible. The attainment of it, consequently, would in some way undercut the foundations of our reality. Take, for example, the wish to grow wings, or the wish to live in another epoch, or the wish to turn back time: such wishes aim for something whose realization would simultaneously undercut the very laws of reality itself and, ergo, extinguish the wisher in the process.

The nature of the object desired might further cause a wish to be of idle status even if its realization is possible. Take for example my wish to have my oil painting accepted for first prize in an art competition. I can toil on the painting up until the deadline, although once it is submitted (ceteris paribus ${ }^{23}$ ) the realization of my wish is out of my hands. Instead, the realization depends on the caprice and estimations of the chosen judges. My will persists in the same world but the time for action on the desired object is beyond my powers. Thus I might wish incessantly for the victory, yet there is nothing causal in the representation apart from a restless longing without concomitant striving. The object is possible, but its realization is (now) dependent on the wills of others.

Now how can we diagnose the logical structure of moral wishing in light of these considerations of idle wishing? To begin, its object, Kant states, is neither known to be possible nor impossible. Certainly there are no laws of nature of which we know that make an ethical commonwealth impossible. Thus in contrast to such idle wishing, moral wishing is marked by an agnosticism regarding the realizability of its object. This distinction is key because it makes moral wishing rationally consistent. By contrast, much idle wishing remains inherently irrational due to its 
aiming at objects that remain, in principle, impossible. It remains, for example, irrational for me to continue wishing and longing that I suddenly go through a metamorphosis and awake tomorrow morning as a beetle. Moral wishing, however, is distinct because its object is not, in principle, impossible. Thus it is not irrational to maintain this wish; it only appears to be a contradiction of the agent with herself when not viewed from the species-level perspective.

Next, the nature of the highest good is not one that can be idle in the second sense. The object is not one with a particular nature that excludes the possibility of $m y$ working towards it in some way. As the end of creation and an object for us to strive after as a duty of our species, we are all called to action. Nor would it make sense to say that some people should be striving after its realization while others may sit back and watch. Indeed, the highest good, whose nonimpossibility we just established, is something that remains partially in our control, in so far as we are members of a species whose final end it is to bring about such a realm. Thus we ought and can (in a special sense) work towards its realization.

Following from all this, we can further distinguish idle and moral wishing by analysing the nature of the relation between the agent and the object. Idle wish maintains an impetus that (because it is in essence irrational) remains necessarily self-defeating or utterly vain in its expenditures. The idle wish, as desire, starts our volitional motor and expends our practical energies for nothing. It is a longing without results. A moral wish, however, is not inherently irrational. It represents an exertion (on our parts as individuals) that has the potential to exert a real causal influence with real results (when taken as members of a morally-determined species). Why? Moral wishing's aim is nothing but an extension of the moral law, which is rational to its core. Indeed, Kant thinks that it is an observance of duty to maintain a standing moral wish that one become worthy of such an ethical community. This personal, standing wish is further 
encouraged by that moral wish embodied in the public sphere of morally attentive groups. One cannot help but feel impelled to work towards its realization. The fact that the object is not impossible does not on its own make itself realizable; however, the non-impossibility allows a space of uncertainty in which to strive and long. However, this space of uncertainty is to be filled with determinant, moral actions.

In setting idle wishing in contrast with moral wishing, one might reasonably ask: why does moral wishing still qualify as a form of wishing, in the technical sense, at all? The answer is quite simple: moral wishing remains a wish because the objects of moral wishing extend beyond what an individual can expect to realize in any one instance of action. My moral, efficacious wishing remains entangled with objects that I will not be able to directly and immediately make manifest. Thus even a moral wish remains a wish.

Also, one might fairly wonder what differentiates wishing from hoping. After all, hoping also seems to be a practical state of mind trained at objects of reason that cannot be given in possible experience. What is distinctly volitional about wishing? Kant never offers anything beyond his assurances in the revised footnote that wishes retain their 'relation as causes, hence the representation of their causality'. My attempt at an answer - by playing a variation on a theme by Hector-Neri Castañeda in Thinking and Doing (1975) - goes something as follows. Let us define faith as a theoretical cognition aimed at an object that lacks an intuition and hope as a theoretical-practical ground for maintaining faith. Faith and hope, to use a helpful and deeply insightful distinction of Castañeda's, are purely propositional in structure in that they provide content for thinking related to the practical, rather than directly connecting the actor to the doing of the practical. Wishing, in contrast, is practitional. That is to say, in Kant's technical sense, wishing would count as what Castañeda calls a 'practition', which provides 'unity of content' for 
intentions (Castañeda 1975: 273). My wish to be of a better moral disposition is distinct from my hope for the same thing. A wish, as causal, is a practition because 'it is practical: it is connected with action in a very special way' (275), i.e. 'it has a certain characteristic actional quality' (276). It is a representation that connects me and a possible action along 'with a signal of its practical or causal openness' (280). My hope does not gear me up to act, rather signals in me a lightened state of mind or an expectation for the possible cognition of things to come. My hope, I would venture, leaves no causal openness since it signals one's utter lack of power. My wish is causal because it connects me with an intention that prepares me to work on its coming to pass - or to actively cause myself to be of such a character working towards such great projects. Now an idle wish remains practitional as opposed to propositional. However, it should be clear from the analysis above that an idle wish varies importantly from a moral one. When left idle, the causal component of wishing is wasted since its object represents an essentially irrational goal. To put it metaphorically: in contrast to moral wishing, idle wishing is flooring the gas pedal of a car propped up on cinder blocks with its wheels missing.

With roughly such considerations, it seems quite likely that Kant came to completely recant his former antipathy towards wishing. For now, rather than wishing being a worthless species of desire, it has become a duty in one special sense. By morally wishing, we become primed for activity in the world to bring about the highest good, the ethical community that we owe to the species of which we are emblems. Moreover, if I am correct, then it is no surprise that Kant came to see this form of desire as teleologically interesting - for it directs our will and transforms proximal instances of willing into a diachronic process of striving based on our solidarity with our species. In the Metaphysics of Morals, in reference to the highest good in the form (now) of 'perpetual peace', Kant points out 'we must act as if it is something real, though 
perhaps it is not' (MS, 6: 354). Indeed, 'even if the complete realization of this objective always remains a pious wish [ein frommer Wunsch], still we are certainly not deceiving ourselves in adopting the maxim of working incessantly toward it' (MS, 6: 354). And of most importance, he begins the next sentence with an unequivocal assertion regarding this pious wish: 'For this is our duty' (6: 355 , my emphasis). It is our duty, as members of the human species to wish for such a world and, in so doing, make it a standing, efficacious one aimed at our character so that we increase in our striving after it. When it comes to wishing, we ask not: was können wir wünschen? Rather: was sollen wir wünschen ${ }^{24}$

\section{Notes}

${ }^{1}$ With the exception of Letter 533 (which is my own translation), all English translations are drawn from the Cambridge Edition of the Works of Immanuel Kant. Citations are by abbreviations of the Akademie Ausgabe ( $A A$ ) titles, followed by the latter's volume and page numbers. The following abbreviations are employed: $K p V=$ Critique of Practical Reason (Kant 1996a); KU = Critique of the Power of Judgement (Kant 2000); GMS= Groundwork for the Metaphysics of Morals (Kant 1996a); RGV=Religion within the Boundaries of Mere Reason (tr, George di Giovanni in Kant 1996b); MS = Metaphysics of Morals $($ Kant 1996a); IaG = 'Idea for a Universal History' (tr. Allen W. Wood in Kant 2007); Br=Correspondence [Briefe]; Refl = Notes and Fragments [Reflexionen $]($ Kant 2005); V-Anth/Pillau = Anthropology Pillau, VAnth/Mron = Anthropology Mrongovius (Kant 2012).

${ }^{2}$ Engstrom (2009: 68, n. 2) means by wish, for example, a technical term as well, but with a much broader sense: wish is 'a judgment concerning what is simply good'. I am concerned exclusively with the narrower sense. 
${ }^{3}$ Höwing (2013), Morrisson (2008: 33-4) and McCarty (2009: 16-7) discuss the difference between wishing and Willkür in light of the footnote from the $K U$. Höwing offers the most detailed exploration of wishing (see note 9 below). The latter two, however, do not reference moral wishing in its causal sense. Moreover, though all cite the footnote, none mentions the changes in the elements of wishing between its two versions. The paucity of literature is further evidenced by Volume 3 of the Kant-Lexicon (2015), which references just two works. The entry on Wunsch itself describes its 'philosophical function' as playing 'no central role'; instead, it is employed only as 'conceptual contrast' to real instances of willing (2015: 2692a, my translation). ${ }^{4}$ The $A A$ edition of the $K U$ lacks an editorial remark letting the reader know that the footnote was first published in the second edition of 1793. Consequently, one might think that the positive, revised footnote was added in the same time period as the negative first introduction version.

${ }^{5}$ Rehberg's criticism can be found in his 1788 review of the $\mathrm{Kp} V$ in the Allgemeine LiteraturZeitung, where he rejects Kant's definition of the will because 'We desire many things of which we know that we cannot be the cause of their reality'.

${ }^{6}$ Traces of Kant's antipathy can already be found from around 1753 . In reflections he penned for the prize competition put forth by the Prussian Royal Academy of Sciences regarding Leibniz's system of optimism, Kant praises virtue as the ultimate source of happiness, from which he concludes: 'Since virtue, therefore, finds no lack, wishing is worthless' (Refl 3703, 17 : 229-30). More famously, in Groundwork of the Metaphysics of Morals, Kant refers to a 'mere wish' in contrast to the 'good will', since a mere wish fails to be a 'straining of every means so far as they are in our control' (GMS, 4: 394). 
${ }^{7}$ E.g. in the Anthropology Pillau (1777-8) he claims that nothing is gained from such 'idle desires', for they 'cannot move our activity' ( $V$-Anth/Pillau, 25: 795). Over time, however, he seems to soften on idle wishing's efficaciousness, for in the Anthropology Mrongovius (1784-5), he refers to idle desires that 'move us to try our power' (V-Anth/Mron, 25: 1335). This stance is close to Kant's position in the first introduction version of the footnote.

${ }^{8}$ This position regarding the object of our moral striving remains in place all the way until MS: 'What is incumbent upon us as a duty is rather to act in conformity with the idea of that end, even if there is not the slightest theoretical likelihood that it can be realized, as long as its impossibility cannot be demonstrated either' (MS, 6: 354, my emphasis). Furthermore, he keeps his definition of wishing consistent with the positive re-evaluation of it in that it only differs from Willkür in that it is 'not joined' with 'one's consciousness of the ability to bring about its object by one's actions' (MS, 6: 213).

${ }^{9}$ Kant refers, confusingly, to 'ultimate end [letzter Zweck]' and 'final end [Endzweck]', which, as Höffe (2008) points out, could both be called 'finis ultimus' (Höffe 2008: 294). However, Höffe points out that Kant uses these as distinct terms. Ultimate end is a 'highest, a superlative end [Superlativ-Zweck]', while a final end 'is an "ultimate end plus $\mathrm{x}$ "; thus, a superlative, which transcends even the superlative character [Superlativ-Charakter]' (ibid., my translation). Thus one can differentiate between the human being as ultimate end, and that which qualifies as an end transcending the individual, i.e. the moral vocation of our species. Cf. also Allison (2012: 40).

${ }^{10}$ Cf. Allison (2012: 36) for a discussion as to whether the necessity of such a judgement makes sense. 
${ }^{11}$ I note that Kant does refer to a 'moral wish' in the $\operatorname{Kp} V(5: 115,118)$. Moral wish is related to the highest good, yet (at this point) a highest good that is not yet the final end of creation and not yet related to a species-level duty.

${ }^{12}$ See e.g. Idea for a Universal History with a Cosmopolitan Aim (hereafter: IaG): 'an arrangement that does not attain to its end, is a contradiction in the teleological doctrine of nature' (8: 18). Cf. also $K U, 5: 370-1,471-472$ n.

${ }^{13}$ In a reflection from the 1790 's, Kant tethers faith to dutiful wishing in an interesting manner: 'Belief - I would gladly believe what I wish for, if only I had a reason for it. ... If, however, it is a duty to wish for something (for there is no duty to believe), then I am right to believe it if I can. - If, however, I cannot believe it (e.g., a future life), then I have reason enough to act as if such a thing were the case' (Refl 2503, 16: 395-6, my emphasis).

${ }^{14}$ Förster (2012) offers a clear account of this: '[T]o will something and to take an interest in its existence are for Kant synonymous. It is for this reason that we as moral beings have an interest in the consequences of our deeds' (131). Thus the importance of the discovery of the principle of purposiveness becomes all the more important for us: we have an interest 'that [nature's] physical laws allow for the achievement of our moral purposes' (132). And, since natural beauty is a fact of experience, which 'cannot be understood as exceptions to natural law', our reflective judgments must be grounded 'on the principle that nature ... accommodates itself to the power of judgment' (136), showing that principles of purposiveness (and, ergo, intention) can be harmonized with nature and its laws.

${ }^{15}$ Even with this teleological component, the highest good as the end of creation remains in need of support from God due to our feeling powerless. We have grounds 'for assuming this cause ... even if for nothing more than avoiding the danger of seeing that effort as entirely futile in its 
effects and thereby flagging in it' (KU, 5: 446, my emphasis). We must assume that there is a God as a form of moral support qua moral author of the universe. Not as support in what He will create, but rather in what He has already created in us, his moral agents.

${ }^{16}$ See Letters 522, dated July 30, 1792, and 574, dated May 4, $1793(\mathrm{Br}, 11: 336,415)$ for confirmation that he was working on all four parts of $R G V$ during the time period between the first and second editions.

${ }^{17}$ See also $I a G, 8: 24$.

${ }^{18}$ The translation by Di Giovanni can mislead one because Kant only states that divine blessedness 'verheißt und sichert' the expectation of the final, moral end being attained. 'Verheißen' is better translated, I think, as 'portends' or 'bodes', which surely implies building up hope for something. But 'sichert', or 'secures', is also not synonymous with 'guarantees', since securing something does not inevitably promise its realization. Something secured might also be undone if care is not taken. Di Giovanni's translation of 'guarantee', thus, is too strong. ${ }^{19}$ Prayer conceived as a performative utterance that one must do in order to please God represents nothing more than a 'superstitious delusion' ( $R G V, 6: 194)$. The utterance of a prayer as such brings nothing about in reality.

${ }^{20}$ Biss (2015) argues for Kant's notion of moral striving being a ‘diachronic process' (2) in which one works on those aspects of one's character that aid in strengthening the will. Her claim that moral contemplation viewed as an ongoing activity to cultivate moral 'attentiveness' (12, 14), dovetails nicely with the notion of moral wishing. In fact, moral wishing fits the bill almost to a $\mathrm{T}$ in that it is a 'standing' (read: diachronic) and efficacious (read: causal) practice of working on one's character in both a personal and public dimension. When she writes: 'Wishing does not amount to willing: setting an end requires activity guided by a conception to the end' 
(14), she is thinking simply the notion of idle wishing that Kant spent most of his life mistaking for the only species of true wishing.

${ }^{21}$ Sweet (2013) could help fill out this picture: 'Reason demands that we adopt certain ends - to bring about the moral world - that require us to join ourselves to others in our willing of the good itself. This is achieved in a church based on making public the moral law and its unconditional demands' (Sweet 2013: 183). Wishing serves precisely this function in its communal sense. Indeed, it does precisely what she seeks to describe as 'attending church' (ibid.). However, the external form of this church remains unbound to dogmatic faiths and instead to rational faith. Thus we need not exclusively think of Christianity as the church, despite Kant's explicit sympathy for it. Another possible reading would be to connect this public level of moral wishing with a notion of a 'duty of publicity', as put forth by Melissa Zinkin (2016: 239): 'What I have in mind as a duty of publicity is the negative duty not to conceal or keep secret our maxims.'

${ }^{22}$ Thomas Höwing (2013) concludes (correctly) that Kant has two different notions of wish. He then asks 'Why the representation contained in a wish should also possess a causal relation to the object, if this ... cannot in the least lead to the result that the object will be brought about' (Höwing 2013: 44, my translation). To this question, my paper gives strong answer. The immanent grounds that brought him to consider wish as an exercise, or actus of the will, are bound up with our species-level duty to strive after the highest good. Although Höwing refers repeatedly to the relevant footnote in the $K U$, he overlooks the relevant changes that offer the clue as to why Kant's conception of wishing evolved to become a causal species of desire for the will. 
${ }^{23}$ I say 'ceteris paribus' for the reason that there are, perhaps, ways of actually bringing about the object of my wish via unethical means. I could, for example, bribe the judges (should they be of such a character) and, thereby, take control over the process. However, if one's wish is not simply to win the contest, but also to win it because one is deserving - then such diabolical means to victory undercut the essence of the wish, namely, to have one's work recognized for its value because it actually possesses it.

${ }^{24}$ I would like to thank Eckart Förster and Dean Moyar for their helpful comments on early drafts of this paper. Also, I would like to thank the participants in the 2016 North American Kant Society Eastern Study Group Meeting for their stimulating engagement with and insights regarding a truncated version of this paper; their feedback formed much foundation for further development of my ideas going forward. In particular, Paul Franks offered some key questions that helped me think of things from a different angle. Finally, an anonymous reviewer offered many observations of great value that have significantly improved the end product. It truly takes a village.

\section{References}

Allison, Henry (2012) 'Teleology and history in Kant: the critical foundations of Kant's philosophy of history'. In Amélie Rorty and James Schmidt (eds), Kant's 'Idea for a Universal History with a Cosmopolitan Aim': A Critical Guide. (Cambridge: Cambridge University Press), pp. 24-45.

Biss, Mavis (2015) 'Kantian Moral Striving'. Kantian Review, 20, 1-23.

Castañeda, Hector-Neri (1975) Thinking and Doing. Dordrecht, Holland: D. Reidel. Engstrom, Stephen (2009) The Form of Practical Knowledge: A Study of the Categorical Imperative. Cambridge, MA: Harvard University Press. 
Förster, Eckart (2012) The Twenty-Five Years of Philosophy. A Systematic Reconstruction.

Translated by Brady Bowman. Cambridge, MA: Harvard University Press.

Höffe, Otfried (2008) 'Der Mensch als Endzweck'. In Otfried Höffe (ed.) Klassiker Auslegen. Kritik der Urteilskraft (Berlin: Akademie Verlag), pp. 289-308.

Höwing, Thomas (2013) 'Das Verhältnis der Vermögen des menschlichen Gemüts zu den Sittengesetz'. In Andreas Trampota, Oliver Sensen and Jens Timmermann (eds) Kant's 'Tugendlehre': A Comprehensive Commentary (Boston: De Gruyter), pp. 25-58.

Kant, Immanuel (2000) Critique of the Power of Judgment. Edited by Paul Guyer. Translated by Paul Guyer and Eric Matthews. Cambridge: Cambridge University Press.

—(1922) Briefwechsel. In Königlich Preußischen Akademie der Wissenschaft (ed.), Kants Gesammelte Schriften. Volume 11.2. Berlin: de Gruyter.

— (1996a) Practical Philosophy. Translated and edited by Mary Gregor. Cambridge: Cambridge University Press.

- (1996b) Religion and Rational Theology. Translated and edited by Allen Wood and George di Giovanni. Cambridge: Cambridge University Press.

— (2005) Notes and Fragments. Edited by Paul Guyer. Translated by Curtis Bowman, Paul Guyer and Frederick Rauscher. Cambridge: Cambridge University Press.

— (2007) Anthropology, History, and Education. Edited by Günter Zöller and Robert B. Louden. Cambridge: Cambridge University Press.

- (2012) Lectures on Anthropology. Edited and translated by Allen W. Wood and Robert B. Louden. Cambridge: Cambridge University Press. McCarty, Richard (2009) Kant's Theory of Action. Oxford: Oxford University Press. 
Morrisson, Iain (2008) Kant and the Role of Pleasure in Moral Action. Athens, OH: Ohio University Press.

Rehberg, August Wilhelm (1828) Sämmtliche Schriften. Volume 1. Hannover: Verlag der Hahn'schen Hofbuchhandlung.

Sweet, Kristi (2013) Kant on Practical Life: From Duty to History. Cambridge: Cambridge University Press.

Willaschek, Marcus, Stolzenberg, Jürgen, Mohr, Georg, and Bacin, Stefano (eds) (2015) KantLexicon. Volume 3. Berlin: de Gruyter.

Zinkin, Melissa (2016) 'Making the Ideal Real: Publicity and Morality in Kant'. Kantian Review, 21, 237-59. 